\title{
Lead (II) Tolerance and Uptake Capacities of Fungi Isolated from a Polluted Tributary in the Philippines
}

\author{
Maini, Zomesh A.N. ${ }^{1, *}$, Aribal, Kiara Marie J. ${ }^{1}$, Narag, Regine Marinelli A. ${ }^{1}$, Melad, Jeorgina Kamella Luanshya T. ${ }^{1}$, Frejas, \\ Juan Angelo D. ${ }^{1}$, Arriola, Luis Alfonso M. ${ }^{1}$, Gulpeo, Pia Clarisse G. ${ }^{1}$, Navarrete Ian A. ${ }^{2}$, Lopez, Crisanto M. ${ }^{1}$ \\ ${ }^{1}$ Department of Biology, School of Science and Engineering, Ateneo de Manila University, Katipunan Avenue, Loyola Heights, 1108 \\ Quezon City, the Philippines \\ ${ }^{2}$ Department of Environmental Science, School of Science and Engineering, Ateneo de Manila University, Katipunan Avenue, Loyola \\ Heights, 1108 Quezon City, the Philippines
}

\begin{abstract}
The Lead [Pb(II)] tolerance and uptake ability of four fungal species, two from the genus Penicillium and two from the genus Talaromyces were investigated in this study. The species were isolated from a polluted tributary and identified to be closest to $P$. canescens, P. simplicissimum, T. macrosporus and another Talaromyces sp. via PCR targeting their internal transcribed spacer 1 and 4 sequences. All isolates have tolerances for up to $2000 \mu \mathrm{g} / \mathrm{mL}$ and $3000 \mu \mathrm{g} / \mathrm{mL} \mathrm{Pb}$ (II) on solid and liquid medium, respectively. Both Penicillium isolates showed increasing removal rates dependent on initial $\mathrm{Pb}$ (II) concentration at 500 to $2000 \mu \mathrm{g} / \mathrm{mL}$, while removal rates of both Talaromyces isolates were not significantly influenced by initial $\mathrm{Pb}(\mathrm{II})$ concentrations. The $\mathrm{Pb}(\mathrm{II})$ uptake of all isolates increased with increasing $\mathrm{Pb}$ (II) concentration but was depressed at $3000 \mu \mathrm{g} / \mathrm{mL}$, with the exception of T. macrosporus. The recorded total uptake capacities for both Penicillium isolates in this study were higher than in most literature, at $7.0-407.4 \mathrm{mg} / \mathrm{g}$ and $50.8-412.6 \mathrm{mg} / \mathrm{g}$ for $P$. canescens and $P$. simplicissimum, respectively. The study also reported the exemplary $\mathrm{Pb}$ (II) uptake capacities of both Talaromyces isolates at 58.9 $601.0 \mathrm{mg} / \mathrm{g}$ and $60.9-402.3 \mathrm{mg} / \mathrm{g}$ for T. macrosporus and Talaromyces sp., respectively. These results signify the excellent $\mathrm{Pb}(\mathrm{II}) \mathrm{removal}$ capabilities of all isolates which may further be developed for use as mycoremediation tools to remove $\mathrm{Pb}$ (II) from heavy metal contaminated environments.
\end{abstract}

Keywords: mycoremediation, tolerance index, biosorption, bioaccumulation, heavy metals

* Correspondence to: Zomesh A.N. Maini, Department of Biology, School of Science and Engineering, Ateneo de Manila University, Katipunan Avenue, Loyola Heights, 1108 Quezon City, the Philippines; E-mail: zmaini@ateneo.edu

Received: December 18, 2018; Accepted: February 22, 2019; Published Online: March 1, 2019

Citation: Zomesh A. N. Maini, Kiara Marie J. Aribal, Regine Marinelli A. Narag, Jeorgina Kamella Luanshya T. Melad, Juan Angelo D. Frejas, Luis Alfonso M. Arriola, Pia Clarisse G. Gulpeo, Navarrete Ian A. and Crisanto M. Lopez, 2019. Lead (II) Tolerance and Uptake Capacities of Fungi Isolated from a Polluted Tributary in the Philippines. http://doi.org/10.26789/AEB.2019.01.004.

Copyright: Lead (II) Tolerance and Uptake Capacities of Fungi Isolated from a Polluted Tributary in the Philippines.(C) 2019 Zomesh A.N. Maini et al. This is an Open Access article distributed under the terms of the Creative Commons Attribution-Noncommercial 4.0 International License, permitting all non-commercial use, distribution, and reproduction in any medium, provided the original work is properly cited and acknowledged.

\section{Introduction}

The exacerbation of heavy metal (HM) concentrations in various substrates is a global ecological and health concern. The direct or indirect release of Arsenic (As), Cadmium (Cd), Chromium (Cr), Copper $(\mathrm{Cu})$, Lead $(\mathrm{Pb})$, Mercury (Hg), Nickel (Ni), Uranium (U), and Zinc (Zn) whether from natural or anthropic origin, increases their environmental levels beyond acceptable thresholds (Chen et al., 2017; He and Chen, 2014; Say et al., 2003a). These HMs become pollutants that are non-biodegradable and are bioaccumulated and biomagnified (Elia et al., 2006) reaching human populations (Wong et al., 2017). Since these HMs are unnecessary for physiological function, minute quantities are enough to cause toxicity to humans and other forms of life as they leach from contaminated sources and enter soil, air, and water (He et al., 2005; Singh et al., 2011).
Heavy metal poisoning due to Lead $[\mathrm{Pb}(\mathrm{II})]$ is one of the most historically well documented causes of disease and disability (Tong et al., 2000). The impact of $\mathrm{Pb}(\mathrm{II})$ on human health affects all ages within a population, ranging from mild discomfort, persistent disability, or severe, multi-systemic dysfunction leading to death (Kim et al., 2015). In the Philippines, $\mathrm{Pb}(\mathrm{II})$ prevalence has been reported in urban centers and rural areas and waterways, making its management and damage mitigation a matter of significance (Navarrete et al., 2017; Ona et al., 2006; Riddell, 2007; Solon et al., 2008). While there are numerous methods available for rehabilitation of $\mathrm{Pb}$-polluted environments, most of these are costly and inefficient, opening avenues for alternative methods of handling $\mathrm{Pb}$ (II) pollution (Ayangbenro and Babalola, 2017).

Mycoremediation has increasingly gained attention due to its cost-effectivity, remarkable success outcomes, 
and fungal structural advantages over other rehabilitative agents (Dixit et al., 2015; Kapahi and Sachdeva, 2017). Filamentous fungi can be used in various environments because of their innate competence and responsiveness to fluctuations in temperature, $\mathrm{pH}$, nutrient availability, and HM concentrations (Oladipo et al., 2018). Fungal species can also accumulate higher amounts of HMs compared to plants (Gube, 2016; Kalac and Svoboda, 2000) and bacteria (Ayangbenro and Babalola, 2017; Rhodes, 2014) This ability is based on several fungal constitutive and adaptive physiological and genetic mechanisms that have been summarized extensively in literature (Bellion, 2006; Gadd, 2007; Gube, 2016).

The total tolerance and metal uptake ability of a fungus is reliant on both bioaccumulation and biosorption (Iskandar et al., 2011; Joshi et al., 2011). The abilities of fungi to intracellularly accumulate (bioaccumulation) and extracellularly adsorb (biosorption) HMs may be dependent on one or more combinations of various biological strategies (Abd El Hameed et al., 2015; Machido et al., 2011; Romero et al., 2006; Zhang et al., 2016). These strategies can be harnessed to serve as means to remove HM toxicants from various substrates. Utilization of fungi that are part of the natural microbiota of an ecosystem exposed to HM damage may become a viable strategy in response to high costs and low effectivity of traditional HM treatment strategies.

\section{Materials and Methods}

\subsection{Sample Collection and Fungal Isolation and Screening}

Soil and water samples were collected at a depth of $5-10 \mathrm{~cm}$

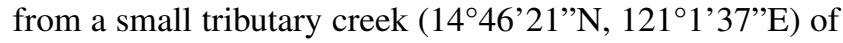
the Marilao River within the Meycauayan-Marilao-Obando River system (MMORS). This area was within range of a health status report that indicated $\mathrm{Pb}$ (II) exposure to the residential areas nearby (Ostrea et al., 2015). Each of the soil samples was diluted with sterile distilled water $\left(\mathrm{sdH}_{2} \mathrm{O}\right)$ in a $1 \mathrm{~g}$ : $9 \mathrm{~mL}$ ratio. Both the diluted soil samples and water samples were diluted with $\mathrm{sdH}_{2} \mathrm{O}$ to produce $1 \times 10^{-1}$ until $1 \times 10^{-5}$ dilutions within $6 \mathrm{~h}$ of obtaining the samples. One $\mathrm{mL}$ of each of these dilutions was placed in sterile disposable petri-plates and pour-plated with $20 \mathrm{~mL}$ potato dextrose agar (PDA, pH 5.5) and incubated at $30^{\circ} \mathrm{C}$ for 5-7 days.

Morphologically distinct mycelia grown on the dilution plates were sub-cultured via point inoculation on PDA supplemented with 1, 10, and $100 \mu \mathrm{g} / \mathrm{mL} \mathrm{Pb}$ (II) and tetracycline (tet, $50 \mu \mathrm{g}$ final concentration/plate). This served to generate isolated cultures and initially screen all isolates for tolerance against $\mathrm{Pb}$ (II). Fungi that survived at $100 \mu \mathrm{g} / \mathrm{mL}$ were then sub-cultured on both PDA/tet and $\mathrm{PDA} /$ tet/ $\mathrm{Pb}(\mathrm{II})$ plates and were incubated for 7-14 days at $30^{\circ} \mathrm{C}$. PDA/tet plates were used for both morphological and molecular identification. The same isolates were cultured on $\mathrm{PDA} /$ tet/ $\mathrm{Pb}$ (II) and were used for tolerance index (TI) measurements and liquid culture uptake tests. All experiments were carried out in triplicate.

\subsection{Morphological Identification}

Standard protocols detailing the macroscopic and microscopic examination of fungal features such as reproductive structures, mycelium, spore shape, size, and color were used to differentiate fungi isolated from the environmental samples for $\mathrm{Pb}(\mathrm{II})$ screening and to corroborate the PCR-based identification (Ellis and Ellis, 1997; Gilman, 2001; Nagamani et al., 2006). Isolates were sub-cultured on PDA/tet every 15 days $\left(5-7\right.$ days growth, $\left.30^{\circ} \mathrm{C}\right)$ to maintain a working stock that was kept at $20^{\circ} \mathrm{C}$.

\subsection{DNA Extraction and PCR Identification}

Genomic DNA was isolated using Vivantis GF-1 DNA isolation kit following the instructions of the manufacturer. Twenty-five grams of fungal tissue from each was used per isolation either being ground to fine powder using liquid nitrogen or through sonication $(50 \mathrm{mHz}, 5$ reps, $15 \mathrm{~s}$ per rep), with a ratio of $50 \mathrm{mg}$ mycelia/ $280 \mathrm{~mL}$ of the extraction buffer provided in the kit. DNA was quantified at 260/280 (IMPLEN NP80) and used as a template for Polymerase Chain Reaction (PCR). The PCR was carried out using the forward primer ITS1F (5'-TCCGTAGGTGAACCTGCGGG-3') and the reverse primer ITS4 (5'-TCCTCCGCTTATTGATATGC3') targeting the internal transcribed spacer (ITS) regions 1 and 4 of fungal DNA. The thermal cycling program was optimized to: initial denaturation $94^{\circ} \mathrm{C}, 2 \mathrm{~min}$ followed by 31 cycles of $94^{\circ} \mathrm{C}$ for $30 \mathrm{sec}, 55^{\circ} \mathrm{C}$ for $30 \mathrm{sec}$, and $72^{\circ} \mathrm{C}$ for $45 \mathrm{sec}$, with a final extension of $72^{\circ} \mathrm{C}$ for $7 \mathrm{~min}$. Each of the amplicons was run on a $2 \% \mathrm{w} / \mathrm{v}$ agarose gel stained with 0.5 $\mu \mathrm{g} / \mathrm{mL}$ EtBr alongside $1 \mathrm{~Kb}$ and $100 \mathrm{bp}$ molecular weight markers at $45 \mathrm{~min}, 100 \mathrm{~V}$ (Vivantis) and were visualized under a UV transilluminator (SynGene).

All PCR products were purified using the Wizard SV Gel and PCR Cleanup System (Promega) following the manufacturer's instructions and were sent to Eurogenetec Asia (Singapore) for standard sequencing. Electropherograms were reviewed manually using Serial Cloner 2.6 (http://serialbasics.free.fr/Serial_Cloner.html), with extraneous sequences of low signature being removed manually. BLAST analysis was performed to compare resulting sequences with known fungal ITS sequences against the NCBI database.

\subsection{Growth Rates and Tolerance Indexes}

Growth rates (GR) and TI measurements were generated via a plate assay. PDA/tet plates were supplemented with $\mathrm{Pb}(\mathrm{II})$ to final plate concentrations of 500, 1000, 2000 and $3000 \mu \mathrm{g} / \mathrm{mL}$. These plates were inoculated with $\sim 1.0 \times 10^{5}$ spores in a $1 \%$ Tween20/Phosphate-buffered saline solution 
(Tween-PBS) from each of the fungal isolates coming from the stock cultures. These were then incubated at $30^{\circ} \mathrm{C}$ for a maximum of 15 days. The diameter $(\mathrm{mm})$ of the mycelial mass was measured daily for the 15-day duration using a digital caliper to generate GRs. Mycelial morphology was photo documented every $24 \mathrm{~h}$. TIs were generated using the GR measurements of all species tested following Dey et al., (2016). The TI shows a ratio of relative growth of each species grown on the $\mathrm{Pb}$ (II) supplemented medium (MSM) against growth of the same species on a non- $\mathrm{Pb}$ (II) supplemented plate. The TI was measured as:

$$
T I=\frac{\text { Fungal growth on } M S M / \text { tet }}{\text { Fungal growth on PDA/tet }}
$$

Tolerance index values $<1$ indicate growth was suppressed by $\mathrm{Pb}$ (II) supplementation; a value of 1 indicates noninfluence of growth by $\mathrm{Pb}(\mathrm{II})$ and a value $>1$ one indicates that growth is enhanced by $\mathrm{Pb}(\mathrm{II})$ supplementation.

\section{5 $\mathrm{Pb}(\mathrm{II})$ Removal Efficiency and Uptake in Liquid Media}

The impact of initial $\mathrm{Pb}$ (II) concentration on the uptake potential of the fungal species was tested using a modified liquid culture set-up based on Mohsenzadeh and Shahrokhi, (2014). Flasks containing $50 \mathrm{~mL}$ of the Potato Dextrose Broth (PDB) were supplemented with $\mathrm{Pb}$ (II) with final concentrations of 500,1000, 2000, and $3000 \mu \mathrm{g} / \mathrm{mL}$ and 100 $\mu \mathrm{g} / \mathrm{mL}$ of tetracycline adjusted with $\mathrm{Na}-\mathrm{P}$ buffer at $6 \mathrm{pH}$. These were inoculated with $100 \mu \mathrm{L}$ of a $\sim 1.0 \times 10^{5}$ spores in Tween-PBS as previously described and then incubated at $30^{\circ} \mathrm{C}, 180 \mathrm{rpm}$ for 15 days. After the incubation duration, the fungal biomass was separated from the liquid medium via gravity filtration using a Whatman $2(47 \mathrm{~mm})$ filter as described by Kiene and Slezak, (2006), letting the media drip into a sterile $50 \mathrm{~mL}$ conical tube. The filtrate, ranging from $45-50 \mathrm{~mL}$, was analyzed using inductively coupled plasma atomic emission spectroscopy (ICP-AES) and the fungal biomass was kept at $-20^{\circ} \mathrm{C}$. Three conical tubes with $50 \mathrm{~mL}$ of sterile $\mathrm{PDB} /$ tet supplemented with $\mathrm{Pb}(\mathrm{II})$ concentrations of 500,1000, 2000, and $3000 \mu \mathrm{g} / \mathrm{mL}$ were also sent as standards for measurement of removal efficiency. The remaining fungal biomass after the filtration was placed in similar containers and was oven dried at $60^{\circ} \mathrm{C}$ prior to measurement of dry weight. All trials were done in triplicate.

Removal efficiency, the percentage of metal removed from the solution $(R, \%)$ was computed using the values obtained from the samples processed through ICP/AES using the following formula (Iskandar et al., 2011):

$$
R=\frac{\left(C_{o}-C_{f}\right)}{C_{o}} \times 100
$$

where $R$ is the Removal Rate, $\mathrm{C}_{o}$ is the predetermined initial $\mathrm{Pb}$ (II) concentration $(\mu \mathrm{g} / \mathrm{mL})$ and $\mathrm{C}_{f}$ is the final $\mathrm{Pb}$ (II) concentration $(\mu \mathrm{g} / \mathrm{mL})$ determined from the ICP/AES measurements.

The amount of metal uptake by the fungi $(q, \mathrm{mg} / \mathrm{g})$ was quantified as follows (Chen et al., 2017):

$$
q=\frac{\left(C_{o}-C_{f}\right) v}{M}
$$

where $q$ is the uptake capacity, $C_{o}$ is the initial $\mathrm{Pb}(\mathrm{II})$ concentration $(\mathrm{mg} / \mathrm{L}) ; C_{f}$ the final $\mathrm{Pb}(\mathrm{II})$ concentration $(\mathrm{mg} / \mathrm{L}) ; V$ the volume of solution $(\mathrm{L}) ; M$ the dry weight of biomass $(\mathrm{g})$.

\subsection{Statistical Analysis}

Triplicates were prepared for all experiments. The data obtained for GR, TI, $R$ and $q$ was analyzed with Two-Way Analysis of Variance (ANOVA). Means were compared with Tukey's Honestly Significant Difference test $(\mathrm{P}<0.05)$ using a repeated-measures multiple-comparisons test (MCT). All statistical analyses were performed using GraphPad (v6.01).

\section{Results}

\subsection{Fungal Identification}

Four fungal species from the mixed soil and water samples survived on $500 \mu \mathrm{g} / \mathrm{mL}$ of $\mathrm{Pb}$ (II) were identified and screened. The ITS-based PCR identified the fungi belonging to the Penicillium and Talaromyces genera. The isolates had closest matches to $P$. canescens (KX258810.1), P. simplicissimum (KM613146.1), T. macrosporus (KU204425.1) and Talaromyces sp. strain Fi5 (MG098734.1) (Table 1).

Table 1. Taxonomic identification of fungal species with similarities on the NCBI database.

\begin{tabular}{llccc}
\hline Lab ID & Closest Species Match & Accession number & $\begin{array}{c}\text { Sequence } \\
\text { Identity (\%) }\end{array}$ & $\begin{array}{c}\text { Query } \\
\text { Coverage (\%) }\end{array}$ \\
\hline Sp AF-01 & Penicillium canescens & KX258810.1 & 99 & 97 \\
Sp F-01 & Penicillium & KM613146.1 & 98 & 75 \\
Sp A-01 & Talaromyces macrosporus & KU204425.1 & 98 & 98 \\
Sp C-01 & Talaromyces sp. strain Fi5 & MG098734.1 & 92 & 99 \\
\hline
\end{tabular}

\subsection{Tolerance Responses to $\mathrm{Pb}(\mathrm{II})$}

The mycelial growth responses and tolerance indices of P. canescens, P. simplicissimum, T. macrosporus, and Talaromyces sp. strain Fi5 varied across different concentrations of $\mathrm{Pb}(\mathrm{II})$, with all species capable of growth at 500, 1000 , and $2000 \mu \mathrm{g} / \mathrm{mL}$ of $\mathrm{Pb}(\mathrm{II})$. Only P. simplicissimum and Talaromyces sp. strain Fi5 grew at $3000 \mu \mathrm{g} / \mathrm{mL}$ of $\mathrm{Pb}$ (II). The tolerance indices derived from the GRs measured over a 15-day interval compared with that of control plates without $\mathrm{Pb}(\mathrm{II})$ supplementation are seen in Figure 1.

The highest TIs for all isolates are generally exhibited at $500 \mu \mathrm{g} / \mathrm{mL}$. The tolerance graphs for both Penicillium species (Fig 1A-B) show that their highest TI is achieved at the early onset of exposure to $\mathrm{Pb}$ (II) at 1-2 days, showing enhanced growth compared to the control, with subsequent decline. $P$ canescens achieves its highest TI $(1.59 \pm 0.17)$ at 

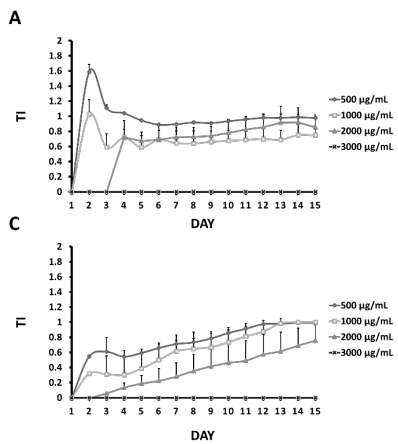
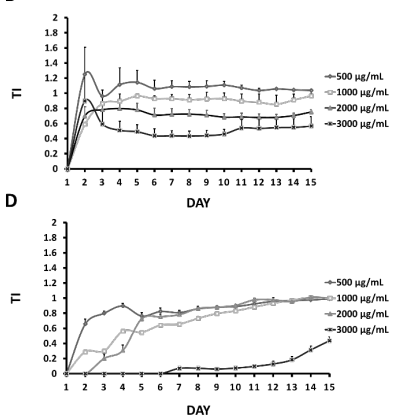

Figure 1. Tolerance index curves of all species at $500 \mu \mathrm{g} / \mathrm{mL}, 1000 \mu \mathrm{g} / \mathrm{mL}$, $2000 \mu \mathrm{g} / \mathrm{mL}$ and $3000 \mu \mathrm{g} / \mathrm{mL}$ of $\mathrm{Pb}$ (II) supplementation for $P$. canescens, (A) P. simplicissimum, (B) T. macrosporus, (C) and Talaromyces sp. strain Fi5 (D). Bars indicate standard deviation of at least three replicates.

day 2 at $500 \mu \mathrm{g} / \mathrm{mL}$ exposure, while $P$. simplicissum obtains its peak TI $(1.25 \pm 0.62)$ at day 2 at $500 \mu \mathrm{g} / \mathrm{mL}$ exposure. $P$. canesens does not reach TI $=1$ after day three, while $P$. simplicissimum has $\mathrm{TI}>1$ only for $500 \mu \mathrm{g} / \mathrm{mL}$ from day 1-15. A decreasing trend in TI is seen with increasing $\mathrm{Pb}(\mathrm{II})$ concentration for both species, with $P$. canescens being completely inhibited at $3000 \mu \mathrm{g} / \mathrm{mL} \mathrm{Pb}$ (II).

Both Talaromyces isolates exhibit slow relative growth on $\mathrm{Pb}$ (II) supplemented media reaching their peak growth $(\mathrm{TI}=$ 1) only at day 15 (Fig 1C-D). T. macrosporus reaches $\mathrm{TI}=$ 1 for $500 \mu \mathrm{g} / \mathrm{mL}$ and $1000 \mu \mathrm{g} / \mathrm{mL}$, while Talaromyces $s p$. reaches $\mathrm{TI}=1$ for all concentrations except $3000 \mu \mathrm{g} / \mathrm{mL}$. $T$. macrosporus shows decreasing $\mathrm{TI}$ as $\mathrm{Pb}(\mathrm{II})$ concentrations increase, being completely inhibited at $3000 \mu \mathrm{g} / \mathrm{mL} \mathrm{Pb}$ (II). Talaromyces $s p$. shows irregular TI fluctuation from days 1-4, with TI at $2000 \mu \mathrm{g} / \mathrm{mL}$ matching and exceeding TIs of the $500 \mu \mathrm{g} / \mathrm{mL}$ and $1000 \mu \mathrm{g} / \mathrm{mL}$ treatment groups starting day 6 . Additionally, the growth of Talaromyces $s p$. is inhibited from days $1-6$ but reaches a maximum TI of $0.57 \pm 0.04$ at day 15 .

Varying relative growth responses were shown by each isolate in response to varying concentrations of $\mathrm{Pb}$ (II) at day 5, 10 and 15. Differences in TI for each isolate exposed to similar $\mathrm{Pb}(\mathrm{II})$ concentrations are seen in Figure 2, while differences in TI per isolate exposed to increasing $\mathrm{Pb}(\mathrm{II})$ concentrations are seen in Figure 3.

Assessing day five (Figure 2A), there are no significant differences $(\mathrm{P}>0.05)$ in TI between isolates exposed to 500 $\mu \mathrm{g} / \mathrm{mL}$. T. macrosporus shows a significantly $(\mathrm{P}>0.05)$ lower TI compared to all the other isolates at 500 to $2000 \mu \mathrm{g} / \mathrm{mL}$ $\mathrm{Pb}(\mathrm{II})$. The growth of all isolates except $P$. simplicissimum are completely inhibited at $3000 \mu \mathrm{g} / \mathrm{mL}$. Progressing to day 10 (Figure 2B), significant $(\mathrm{P}>0.05)$ differences in $\mathrm{TI}$ are seen in $2000 \mu \mathrm{g} / \mathrm{mL}$ where Talaromyces $s p$. has significantly $(\mathrm{P}>0.05)$ higher TI than all other isolates. Talaromyces sp. also begins to show growth at $3000 \mu \mathrm{g} / \mathrm{mL}$, albeit still significantly $(\mathrm{P}>0.05)$ lower than $P$. simplicissimum. Finally, at day 15 (Figure 2C), both P. simplicissimum

A
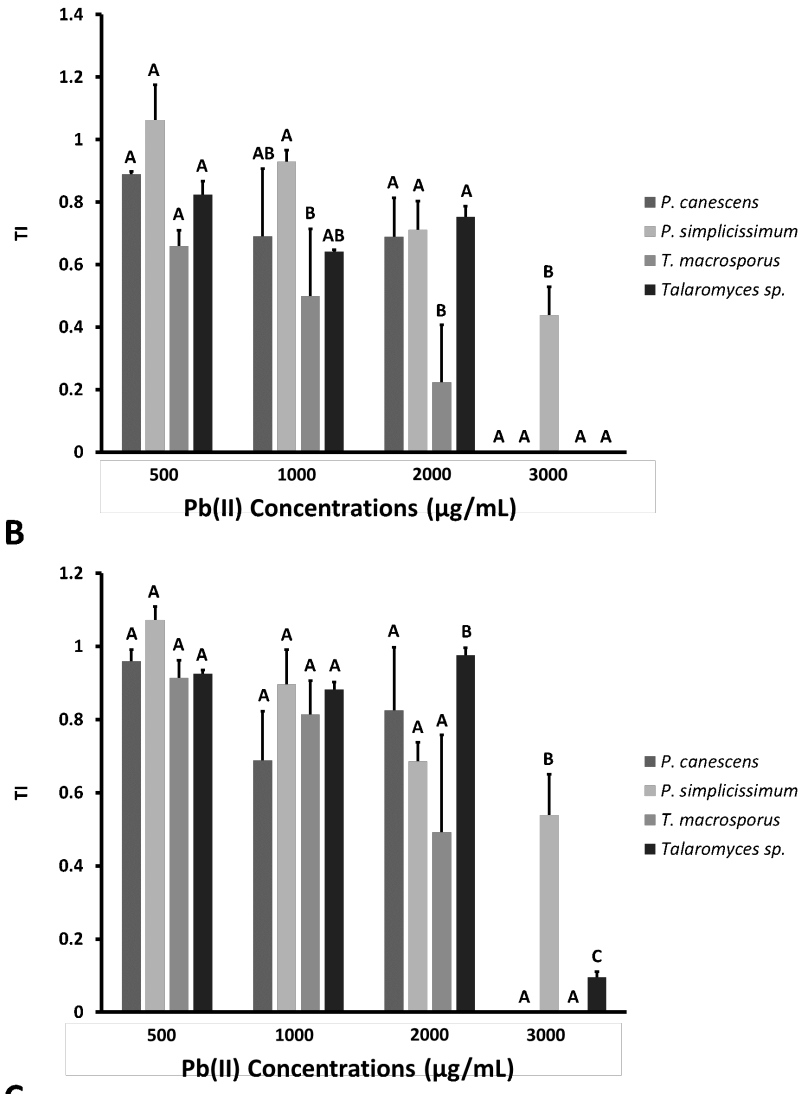

C

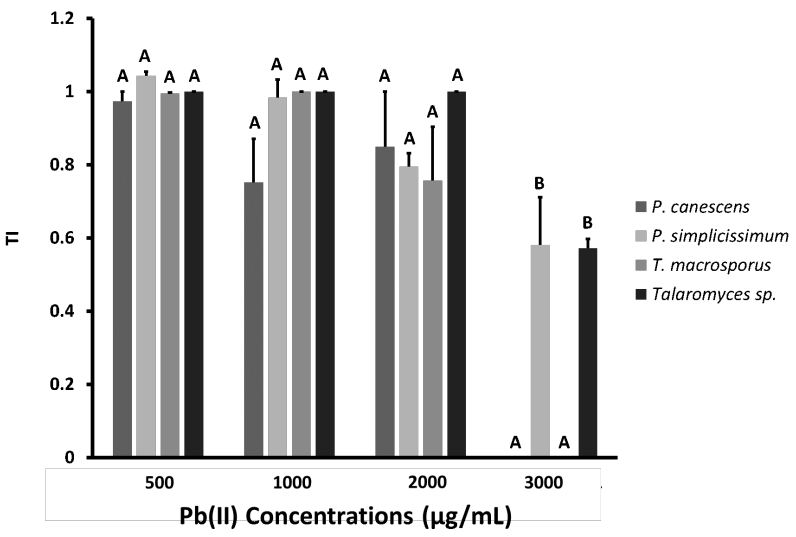

Figure 2. Tolerance Index comparison of all isolates at 500, 1000, 2000, and $3000 \mu \mathrm{g} / \mathrm{mL}$ of $\mathrm{Pb}(\mathrm{II})$ exposure at $30^{\circ} \mathrm{C}$ on day 5 (A), 10 (B) and $15(\mathrm{C})$. Means that share at least one similar letter are not significantly different at Honestly Significant Difference $\left(\mathrm{HSD}_{(0.05)}\right), \mathrm{P}<0.05$. Bars indicate standard deviation of at least three replicates. 
and Talaromyces sp. have significantly $(\mathrm{P}>0.05)$ higher TIs compared to $P$. canescens and T. macrosporus that are inhibited at $3000 \mu \mathrm{g} / \mathrm{mL} \mathrm{Pb}(\mathrm{II})$.

Comparing TI performance for each species as a response to different $\mathrm{Pb}$ (II) concentrations, it can be seen that on day 5 (Figure 3A), TI at 500-2000 $\mu \mathrm{g} / \mathrm{mL}$ are not significantly $(\mathrm{P}>0.05)$ different from one another, with the $3000 \mu \mathrm{g} / \mathrm{mL}$ test concentration completely inhibiting all isolates other than $P$. simplicissimum. Continuing to day 10 (Figure 3B), no significant $(\mathrm{P}>0.05)$ differences in TI are seen for all isolates at $500 \mu \mathrm{g} / \mathrm{mL}$ and $1000 \mu \mathrm{g} / \mathrm{mL}$. P. simplicissimum and $T$. macrosporus show significantly $(\mathrm{P}>0.05)$ lower $\mathrm{TI}$ at 2000 $\mu \mathrm{g} / \mathrm{mL}$ and $3000 \mu \mathrm{g} / \mathrm{mL}$ compared to other test concentrations, while $P$. canescens and T. macrosporus still completely inhibited at $3000 \mu \mathrm{g} / \mathrm{mL}$. Reaching day 15 (Figure 3C), $P$. canescens and Talaromyces sp. have similar TI trends for 500 to $2000 \mu \mathrm{g} / \mathrm{mL} \mathrm{Pb}(\mathrm{II})$, while $P$. simplicissimum and $T$. macrosporus have significantly $(\mathrm{P}>0.05)$ higher TI at 500$1000 \mu \mathrm{g} / \mathrm{mL}$ versus $2000-3000 \mu \mathrm{g} / \mathrm{mL}$, with $P$. canescens and T. macrosporus still completely inhibited at $3000 \mu \mathrm{g} / \mathrm{mL}$.

\subsection{Removal Efficiency}

The removal efficiency for $\mathrm{Pb}(\mathrm{II})$ for each isolate exposed to the test $\mathrm{Pb}$ (II) concentrations grown on liquid PDB (Table 2) reveals increasing $\mathrm{R}$ as $\mathrm{Pb}(\mathrm{II})$ increases from 500-2000 $\mu \mathrm{g} / \mathrm{mL}$ for all species except $P$. simplicissimum which has a higher TI at $2000 \mu \mathrm{g} / \mathrm{mL}(98.25 \pm 0.1)$ than at $1000 \mu \mathrm{g} / \mathrm{mL}$ $(97.37 \pm 0.3)$. All isolates except $T$. macrosporus have their lowest TI at $3000 \mu \mathrm{g} / \mathrm{mL}$. Removal rates $>95 \%$ are observed for both Talaromyces isolates for $\mathrm{Pb}$ (II) concentrations $<2000 \mu \mathrm{g} / \mathrm{mL}$. T. macrosporus shows $<2 \%$ variation in $\mathrm{R}$ regardless of $\mathrm{Pb}(\mathrm{II})$ concentration, while Talaromyces $s p$. removal is maintained at $>98 \%$ from $500-2000 \mu \mathrm{g} / \mathrm{mL}$ exposure only lowering to $51.7 \%$ at $3000 \mu \mathrm{g} / \mathrm{mL}$ of $\mathrm{Pb}(\mathrm{II})$. All isolates except T. macrosporus have peak removal efficiencies at $2000 \mu \mathrm{g} / \mathrm{mL}$. $P$. canescens has the poorest removal efficiency at $21-77 \%$, while $T$. macropsorus consistently tops all other isolates at $97-99.5 \%$.

Table 2. Mean removal efficiency $(R)$ rates of $P$. canescens, $P$. simplicissimum, T. macrosporus and T. macrosporus sp. exposed to 500 , 1000,2000 , and $3000 \mu \mathrm{g} / \mathrm{mL} \mathrm{Pb}(\mathrm{II})$.

\begin{tabular}{|c|c|c|c|c|}
\hline \multirow{2}{*}{$\begin{array}{c}\mathrm{Pb}(\mathrm{II}) \text { concentration } \\
(\mu \mathrm{g} / \mathrm{mL})\end{array}$} & \multicolumn{4}{|c|}{$R(\%)$} \\
\hline & 500 & 1000 & 2000 & 3000 \\
\hline P. canescens & $12.28 \pm 4.0$ & $49.83 \pm 8.3$ & $77.78 \pm 3.7$ & $58.94 \pm 2.0$ \\
\hline P. simplicissimum & $87.54 \pm 6.8$ & $98.25 \pm 0.1$ & $97.37 \pm 0.3$ & $35.75 \pm 5.6$ \\
\hline T. macrosporus & $97.92 \pm 0.2$ & $98.56 \pm 0.3$ & $99.30 \pm 0.1$ & $99.50 \pm 0.1$ \\
\hline Talaromyces $s p$ & $98.34 \pm 0.6$ & $99.58 \pm 0.1$ & $99.69 \pm 0.1$ & $51.69 \pm 4.2$ \\
\hline
\end{tabular}

Comparing isolate performance at each test concentration, T. macropsorus has the most consistent removal ability, having no significant $(\mathrm{P}<0.05)$ differences in removal percentage from $500 \mu \mathrm{g} / \mathrm{mL}$ to $3000 \mu \mathrm{g} / \mathrm{mL} \mathrm{Pb}$ (II) (Figure 4C). Talaromyces sp. maintains $>90 \%$ removal from $500-2000 \mu \mathrm{g} / \mathrm{mL} \mathrm{Pb}(\mathrm{II})$ (Figure 4C) but significantly $(\mathrm{P}<0.05)$ drops in removal at $3000 \mu \mathrm{g} / \mathrm{mL}$. P. canescens
A

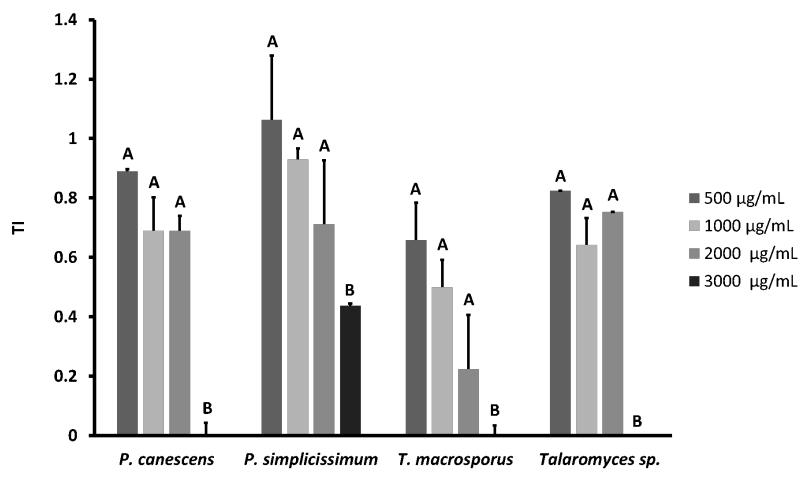

B

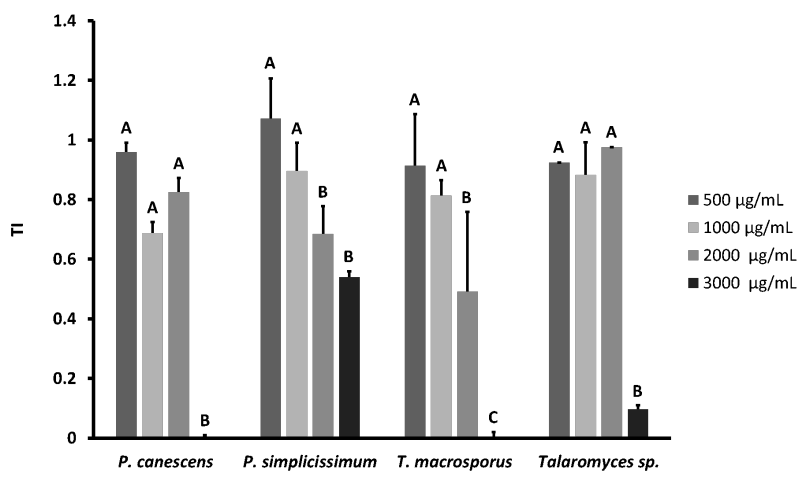

C

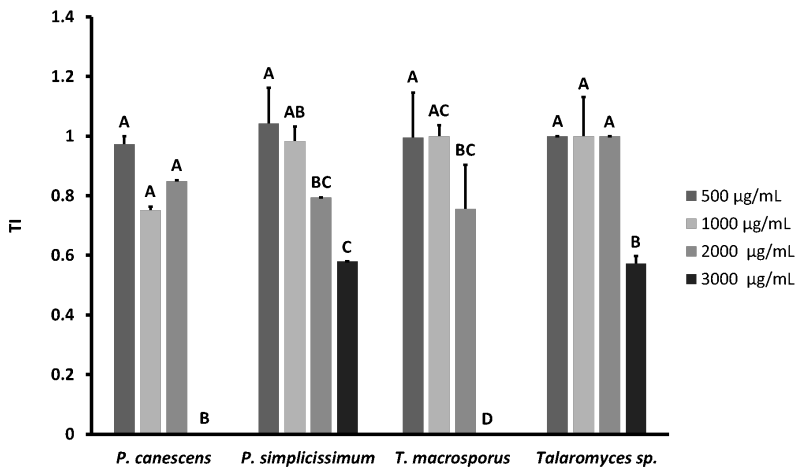

Figure 3. Tolerance Index comparison per isolate exposed to 500, 1000, 2000 , and $3000 \mu \mathrm{g} / \mathrm{mL}$ of $\mathrm{Pb}(\mathrm{II})$ at $30^{\circ} \mathrm{C}$ on day 5 (A), 10 (B) and $15(\mathrm{C})$. Means that share at least one similar letter are not significantly different at Honestly Significant Difference $\left(\mathrm{HSD}_{(0.05)}\right), \mathrm{P}<0.05$. Bars indicate standard deviation of at least three replicates. 
has the most variable response to the different in $\mathrm{Pb}(\mathrm{II})$ concentrations of all the species (Figure 4A), with different removal rates at all test concentrations. P. simplicissimum has a higher $\mathrm{R}$ at $1000 \mu \mathrm{g} / \mathrm{mL}$ and $2000 \mu \mathrm{g} / \mathrm{mL}$, both having significantly $(\mathrm{P}<0.05)$ higher compared to $500 \mu \mathrm{g} / \mathrm{mL}$ and $3000 \mu \mathrm{g} / \mathrm{mL}$ of $\mathrm{Pb}(\mathrm{II})$ (Figure $4 \mathrm{~B}$ ).
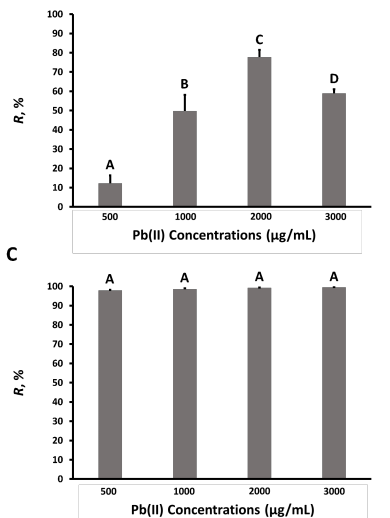

B

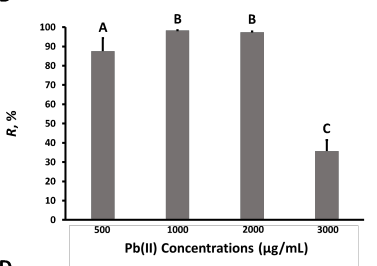

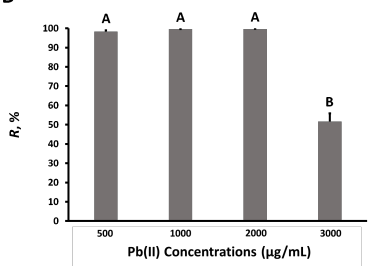

Figure 4. Removal efficiency, $R$, of $P$. canescens(A), $P$. simplicissimum (B), T. macrosporus (C) and Talaromyces sp. (D) exposed to $500 \mu \mathrm{g} / \mathrm{mL}$, $1000 \mu \mathrm{g} / \mathrm{mL}, 2000 \mu \mathrm{g} / \mathrm{mL}$, and $3000 \mu \mathrm{g} / \mathrm{mL} \mathrm{Pb}(\mathrm{II})$. Means that share at least one similar letter are not significantly different at Honestly Significant Difference $\left(\mathrm{HSD}_{(0.05)}\right), \mathrm{P}<0.05$. Bars indicate standard deviation of at least three replicates.

Assessment of the removal of each species per test concentration (Figure 5) shows that at $500 \mu \mathrm{g} / \mathrm{mL}$ and $1000 \mu \mathrm{g} / \mathrm{mL}$, both Penicillium isolates have significantly lower removal than the Talaromyces isolates. At $1000 \mu \mathrm{g} / \mathrm{mL}$ and 2000 $\mu \mathrm{g} / \mathrm{mL}$, only $P$. canescens has significantly $(\mathrm{P}>0.05)$ lower removal compared to all isolates. At $3000 \mu \mathrm{g} / \mathrm{mL}$, each isolate has significantly $(\mathrm{P}>0.05)$ different $R$ with $T$. macrosporus having the highest computed removal efficiency.
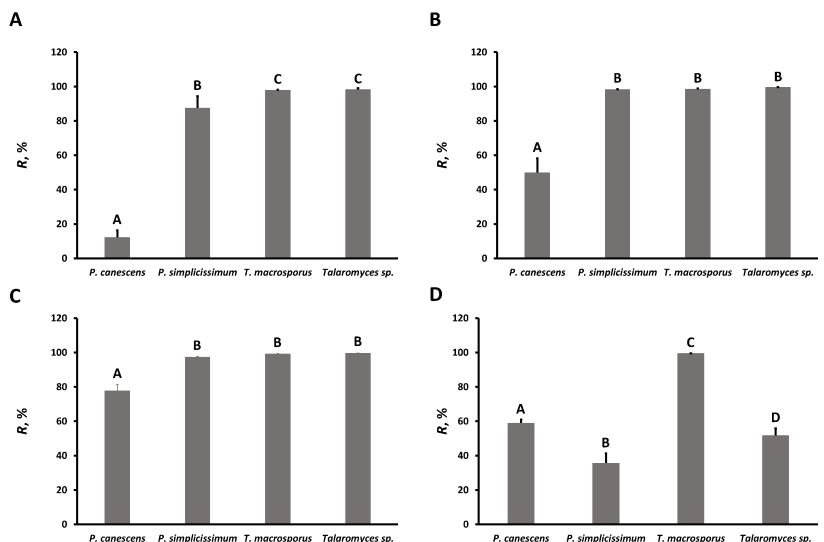

Figure 5. Removal efficiency, $R$, of $P$. canescens, $P$. simplicissimum, $T$. macrosporus and Talaromyces sp. exposed to $500 \mu \mathrm{g} / \mathrm{mL}$ (A), $1000 \mu \mathrm{g} / \mathrm{mL}$ (B), $2000 \mu \mathrm{g} / \mathrm{mL}$ (C), and $3000 \mu \mathrm{g} / \mathrm{mL}$ (D) $\mathrm{Pb}(\mathrm{II})$. Means that share at least one similar letter are not significantly different at Honestly Significant Difference $\left(\mathrm{HSD}_{(0.05)}\right), \mathrm{P}<0.05$. Bars indicate standard deviation of at least three replicates.

\subsection{Uptake of $\mathrm{Pb}$ (II) in Liquid Medium}

Differences in uptake capacity $(q)$ are seen among the different isolates (Table 3). P. canescens had the lowest $q$ among all isolates from $500 \mu \mathrm{g} / \mathrm{mL}$ to $2000 \mu \mathrm{g} / \mathrm{mL} \mathrm{Pb}$ (II), while $P$. simplicissimum had the lowest $q$ at $3000 \mu \mathrm{g} / \mathrm{mL}$. Talaromyces sp. had the highest $q$ from 500-2000 $\mu \mathrm{g} / \mathrm{mL}$, while $T$. macrosporus had the highest $q(601.0 \pm 3.6 \mathrm{mg} / \mathrm{g})$ at $3000 \mu \mathrm{g} / \mathrm{mL}$.

Table 3. Mean uptake capabilities ( $q$ ) of $P$. canescens, $P$. simplicissimum, $T$. macrosporus and T. macrosporus sp. strain Fi5 exposed to 500, 1000, 2000, and $3000 \mu \mathrm{g} / \mathrm{mL} \mathrm{Pb}(\mathrm{II})$.

\begin{tabular}{|c|c|c|c|c|}
\hline \multirow{2}{*}{$\begin{array}{c}\mathrm{Pb} \text { (II) concentration } \\
(\mu \mathrm{g} / \mathrm{mL})\end{array}$} & \multicolumn{4}{|c|}{$q(\mathrm{mg} / \mathrm{g})$} \\
\hline & 500 & 1000 & 2000 & 3000 \\
\hline P. canescens & $7.03 \pm 2.6$ & $92.3 \pm 3.0$ & $407.4 \pm 5.7$ & $370.6 \pm 2.9$ \\
\hline P. simplicissimum & $50.79 \pm 3.2$ & $223.6 \pm 3.7$ & $412.6 \pm 4.9$ & $213.4 \pm 9.0$ \\
\hline T. macrosporus & $58.85 \pm 0.8$ & $226.2 \pm 1.3$ & $516.1 \pm 1.2$ & $601.0 \pm 3.6$ \\
\hline Talaromyces $s p$ & $60.88 \pm 2.4$ & $233.5 \pm 3.9$ & $519.1 \pm 2.6$ & $402.3 \pm 7.8$ \\
\hline
\end{tabular}

Comparing uptake values $(q)$ between species (Figure 6), all isolates have their lowest and highest $q$ at $500 \mu \mathrm{g} / \mathrm{mL}$ and their highest $q$ at $2000 \mu \mathrm{g} / \mathrm{mL}$ except $T$. macrosporus which has a higher $q(601.0 \pm 3.6 \mathrm{mg} / \mathrm{g})$ at $3000 \mu \mathrm{g} / \mathrm{mL}$. There are no significant $(\mathrm{P}>0.05)$ differences in $\mathrm{q}$ at 500 and 1000 $\mu \mathrm{g} / \mathrm{mL} \mathrm{Pb}(\mathrm{II})$ aside from $P$. canescens that has significantly ( $>0.05)$ lower uptake compared to all the other isolates. At $2000 \mu \mathrm{g} / \mathrm{mL}$, both Penicillium isolates have significantly lower $q$ compared to both Talaromyces isolates. At 3000 $\mu \mathrm{g} / \mathrm{mL}$, all isolates have significantly $(\mathrm{P}>0.05)$ different $q$ against each other, with $T$. macrosporus having the highest uptake, followed by Talaromyces sp., $P$. canescens, then $P$. simplicissimum. Comparing individual isolate performance against $\mathrm{Pb}(\mathrm{II})$ concentrations (Figure 7), there is a significant ( $\mathrm{P}>0.05$ ) increase in $q$ for all of the isolates from 500 to 2000 $\mu \mathrm{g} / \mathrm{mL}$ of $\mathrm{Pb}(\mathrm{II})$. All isolates except $T$. macrosporus have a significant decline in $q$ at $3000 \mu \mathrm{g} / \mathrm{mL}$.

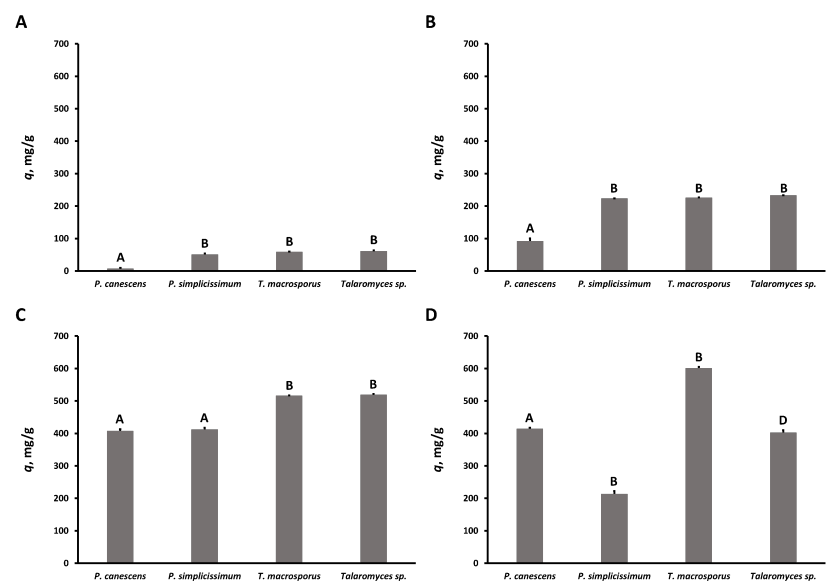

Figure 6. Uptake capacity $(q, \mathrm{mg} / \mathrm{g})$ of $P$. canescens, $P$. simplicissimum, $T$. macrosporus and Talaromyces sp. exposed to $500 \mu \mathrm{g} / \mathrm{mL}$ (A), $1000 \mu \mathrm{g} / \mathrm{mL}$ (B), $2000 \mu \mathrm{g} / \mathrm{mL}$ (C), and $3000 \mu \mathrm{g} / \mathrm{mL}$ (D) $\mathrm{Pb}$ (II). Means that share at least one similar letter are not significantly different at Honestly Significant Difference $\left(\mathrm{HSD}_{(0.05)}\right), \mathrm{P}<0.05$. Bars indicate standard deviation of at least three replicates. 

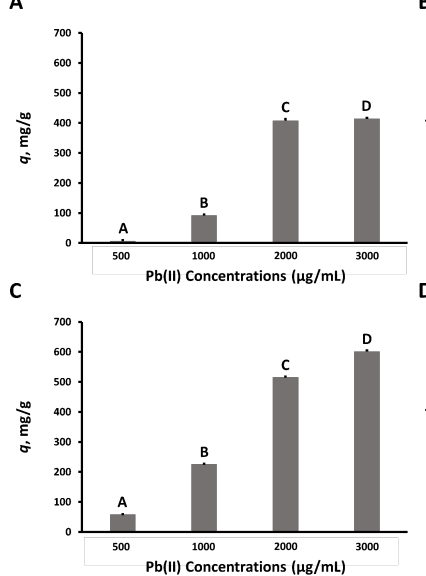
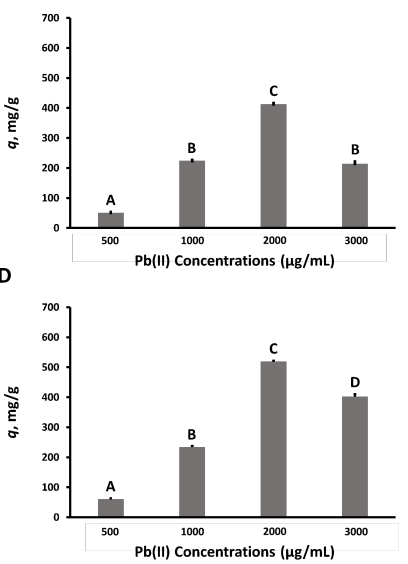

Figure 7. Uptake capacity ( $q, \mathrm{mg} / \mathrm{g}$ ) of P. canescens (A), P. simplicissimum (B), T. macrosporus (C)and Talaromyces sp. (D) exposed to $500 \mu \mathrm{g} / \mathrm{mL}$, $1000 \mu \mathrm{g} / \mathrm{mL}, 2000 \mu \mathrm{g} / \mathrm{mL}$, and $3000 \mu \mathrm{g} / \mathrm{mL} \mathrm{Pb(II).} \mathrm{Means} \mathrm{that} \mathrm{share} \mathrm{at}$ least one similar letter are not significantly different at Honestly Significant Difference $\left(\mathrm{HSD}_{(0.05)}\right), \mathrm{P}<0.05$. Bars indicate standard deviation of at least three replicates.

\section{Discussion}

\subsection{Fungal Tolerance on Solid Media}

This study reports the variable relative growth of all isolates at up to $2000 \mu \mathrm{g} / \mathrm{mL} \mathrm{Pb}$ (II) with $P$. simplicissimum and Talaromyces sp. exhibiting growth up to $3000 \mu \mathrm{g} / \mathrm{mL} \mathrm{Pb(II),}$ all on solid media. Both Penicillium isolates show elevated tolerance indices (TI $>1$ ) 1-2 days post inoculation, while Talaromyces isolates are relatively slow growing, reaching $\mathrm{TI}=1$ at day 15 for almost all concentrations. These are very high survival rates, comparable to some of the highest recorded $\mathrm{Pb}(\mathrm{II})$ growth tolerance, similar to $P$. lilacinus which can tolerate $1437 \mu \mathrm{g} / \mathrm{mL}$ (Zucconi et al., 2003) and Simplicissimum chinense, capable of growth at $5000 \mu \mathrm{g} / \mathrm{mL}$ (Chen et al., 2017) The ability of survival of fungal species in $2000 \mu \mathrm{g} / \mathrm{mL}$ has also been reported in A. fumigatus, $P$. janthanellum, $P$. simplicissimum, and $T$. asperellum (Chen et al., 2017; Iskandar et al., 2011).

Variations in survival rates and TI patterns among isolates of this study reinforce studies that report fungal tolerance as dependent on innate characteristics inherent to the species being studied (Say et al., 2003a; Iskandar et al., 2011), as well as adaptive strategies performed in response to exposure of increased metal concentrations (Valix and Loon, 2003; Zafar et al., 2007). These high tolerances to increased levels of $\mathrm{Pb}(\mathrm{II})$ as opposed to most records in literature may be due to constant exposure to $\mathrm{Pb}$ (II) in their local environment, which can trigger adaptive changes in as fast as 8 days (Valix et al., 2001). Constant exposure of fungi to HMs has been implicated in their ability to develop various tolerance mechanisms (Gorbushina and Krumbein, 2000) and the training of new biotypes to respond to various HMs has been recorded (Chen et al., 2017; Valix et al., 2001).

The lowering of TI for isolates show increased susceptibility to increasing $\mathrm{Pb}$ (II) concentrations on solid media, especially at $3000 \mu \mathrm{g} / \mathrm{mL}$ where $P$. canescens and $T$. macrosporus are completely inhibited. This is to be expected since $\mathrm{Pb}$ (II) is a non-essential element and is not required for any fungal physiological activity. The same result has been shown for fungi from various genera (Iram et al., 2009; Iskandar et al., 2011). While there are fluctuations in TI trends, especially evident in Talaromyces sp., there are no significant $(\mathrm{P}>0.05)$ differences in $\mathrm{TI}$ at days 5, 10, and 15 for each species exposed to $500-1000 \mu \mathrm{g} / \mathrm{mL} \mathrm{Pb}(\mathrm{II})$ concentrations. This suggests that the $\mathrm{Pb}$ (II) tolerance of the isolates may be independent of the HM concentration differences at this range. This is comparable to the static TI change of 13-day old $R$. microsporus grown on 100-400 $\mu \mathrm{g} / \mathrm{mL} \mathrm{Pb}$ (II) (Oladipo et al., 2018).

The ability of the Penicillium genus to survive $\mathrm{Pb}(\mathrm{II})$ has been widely established with abilities of various Penicillium species showing much variation in terms of $\mathrm{Pb}$ (II) tolerance range (Leitão, 2009). Reports for Penicillium species range from survival and growth at $40 \mu \mathrm{g} / \mathrm{mL}$ (Iram et al., 2009) to $2000 \mu \mathrm{g} / \mathrm{mL} \mathrm{Pb}$ (II) (Chen et al., 2017) The TI values for both Pencillium isolates $(>0.9)$ in this study correspond to tolerance values reported by various members of the Pencillium genus that have been subjected to $\mathrm{Pb}(\mathrm{II})$ tolerance tests ranging from 0.79-1.2 TI (Ezzouhri et al., 2009). $P$. canescens and $P$. simplicissimum follow a characteristic growth pattern similar to other Penicillium isolates having 1-2 days of growth lag and a succeeding rapid growth phase when tested against $\mathrm{Ni}, \mathrm{Co}, \mathrm{Fe}, \mathrm{Mg}$ and $\mathrm{Mn}$ (Valix and Loon, 2003). Increased TI after 7 days of $\mathrm{Pb}(\mathrm{II})$ exposure has also been noted in Penicillium sp. isolated from marine environments (Jacob et al., 2013).

Elevated TIs $(\mathrm{TI}>1)$ within the immediate days of isolation for both Penicillium isolates may suggest a predominance of innate biosorptive mechanisms for handling HM influx, affording an abrupt response to HM stress at the early onset of growth. Biosorption rates are faster than bioaccumulation, since these are passive and metabolically independent reactions between the HM and fungal cell walls (Chojnacka, 2010). These cell walls act as the first barrier to the incoming HM, serving to reduce its concentration (Hafez et al., 1997). Support of these results can be found in several studies where $\mathrm{Pb}$ (II) biosorption has been described as a major component of increased fungal tolerance mechanisms in $P$. chrysogenum, $P$. citrinum (Oso et al., 2015), P. janthinellum (Aytar, 2014; Iskandar et al., 2011), P. oxalicum (Svecova et al., 2006), P. purpurogenum (Say et al., 2003a) and P. smplicissimum (Iskandar et al., 2011). Specifically, dried $P$. simplcissimum has been tested as a biosorbent and has shown to adsorb $76.9 \mathrm{mg} / \mathrm{g}$ of $\mathrm{Pb}(\mathrm{II})$, with higher sorption rates at higher initial metal inoculation concentrations (Fan et al., 2008). P canescens has similarly been studied to have $40.4 \mathrm{mg} / \mathrm{g}$ of $\mathrm{Pb}$ (II) showing higher affinity for $\mathrm{Pb}$ compared with $\mathrm{Cd}, \mathrm{Hg}$, and $\mathrm{As}$ (Say et al., 
2003b)

Both Talaromyces isolates show a similar $\mathrm{Pb}$ (II) reaction trend with the Penicillium isolates having a slightly elevated $\mathrm{TI}$ at the first few days of growth most evident at days $1-3$ at $500-1000 \mu \mathrm{g} / \mathrm{mL}$ for T. macrosporus and days $1-4$ at $1000-2000 \mu \mathrm{g} / \mathrm{mL}$. The TI of the Talaromyces isolates, however, does not reach values $>1$ during the duration of the study. The slow relative growth of both Talaromyces isolates may suggest bioaccumulation as an early dominant mechanism in their tolerance strategy. Bioaccumulation is a slower, metabolism dependent process (Chojnacka, 2010), which may explain the lack of a rapid growth phase and why several days are required to reach $\mathrm{TI}=1$ for both isolates. Despite this, comparison of TI response with other members of the Talaromyces genus is difficult since very few members of the Talaromyces genera have been studied for HM tolerance, and data for comparing TI is sparse. However, in terms of tolerance to other HMs, T. wortmanii and T. flavus were found to survive As concentrations at 65-100 $\mu \mathrm{g} / \mathrm{mL}$ (Šimonovičová, 2008), while T. helicus resistance to $\mathrm{Cu}$ at a maximum of $600 \mu \mathrm{g} / \mathrm{mL}$ (Romero et al., 2006), and to $\mathrm{Cd}$ at $10 \mu \mathrm{g} / \mathrm{mL}$ (Massaccesi et al., 2002). A mixture of xanthate-modified thiourea chitosan sponge with Pseudomonas putida and T. amestolkiae biomass has been shown to significantly reduce $\mathrm{Pb}$ (II) in solutions up to 500 $\mu \mathrm{g} / \mathrm{mL}$ (Wang et al., 2017), while one member, T. emersonii, was found to have survival and biosorption potential for uranium (Bengtsson et al., 1995).

Care must be taken in attributing the speed of TI increase at early stages of growth to a predominance of either biosorption or bioaccumulation alone since the total tolerance ability of a fungal strain to withstand a particular HM is a combination of both processes (Joshi et al., 2011). While biosorption is fast, there are a finite number of binding sites that can accommodate a limited number of HM ions (Ayangbenro and Babalola, 2017; Chojnacka, 2010), and sorption rates are dependent on the state of hyphal development (Yetis et al., 2000). Thus, if TI does not significantly increase as time elapses as seen in all isolates of this study, biosorption alone may not be enough to maintain a stable growth rate under $\mathrm{Pb}$ (II) stress. In these cases where sorption sites are filled, it has been suggested that bioaccumulation may take over as the dominant mechanism for tolerance (Jentschke and Godbold, 2000).

\subsection{Removal Efficiency in Liquid Media}

Lead removal efficiencies $(R, \%)$ of each of the isolates show consistent $>90 \% \mathrm{~Pb}$ (II) removal for P. simplicissimum, $T$. macrosporus, and Talaromyces sp. after 15 days of inoculation on liquid media at 500-2000 $\mu \mathrm{g} / \mathrm{mL}$. T. macrosporus continues maintaining $>90 \% R$ until $3000 \mu \mathrm{g} / \mathrm{mL}$, with $\mathrm{Pb}$ (II) concentrations having no significant influence on $R$. Similar $R$ values in response to $\mathrm{Pb}(\mathrm{II})$ have been seen in various fungi such as $A$. macropsorus with $R=88.69 \%$ in $100 \mu \mathrm{g} / \mathrm{mL}$ alkaline solution after $500 \mathrm{~h}$ (Melgar et al., 2007), S. chinenense having $R=80.6 \%$ at $100 \mathrm{ppm}$ (Chen et al., 2017), and T. longibrachiatum having $R=78.84 \%$ at $100 \mathrm{ppm}$ after 15 days (Adeogun et al., 2012). The removal values of $P$. cansescens, ranging from $12 \%-77 \%$ are closer to reports in A. flavus (Akar and Tunali, 2006) and P. lilacinus (Zucconi et al., 2003).

Consistent removal rates independent of HM concentration are shown at $500-2000 \mu \mathrm{g} / \mathrm{mL} \mathrm{Pb}(\mathrm{II})$, most especially in T. macrosporus and P. canescens. P. simplicissimum and Talaromyces sp. show a drop in $R$ at $3000 \mu \mathrm{g} / \mathrm{mL}$, most severe in Talaromyces sp. that drops by $48 \%$ from $2000 \mu \mathrm{g} / \mathrm{mL}$ to $3000 \mu \mathrm{g} / \mathrm{mL}$. These suggest exemplary performance for $\mathrm{Pb}$ removal in liquid media at 500 to $2000 \mu \mathrm{g} / \mathrm{mL}$ for all isolates other than $P$. canescens, and greater susceptibility to $\mathrm{Pb}(\mathrm{II})$ at $3000 \mu \mathrm{g} / \mathrm{mL}$ for all isolates other than T. macrosporus. This is not surprising since most recorded ranges of removal are done with solutions less than $3000 \mu \mathrm{g} / \mathrm{mL}$ (Ahmad et al., 2011; Leitão, 2009).

\subsection{Uptake of $\mathrm{Pb}$ (II) in Liquid Medium}

Both $P$. canescens and T. macropsorus show growth and uptake in liquid media at $3000 \mu \mathrm{g} / \mathrm{mL} \mathrm{Pb}$ (II) despite not being able to grow on solid PDA of the same concentration for TI evaluation. This may be explained by the shaking incubation, which allows better air perfusion and agitation of cells, allowing greater access to nutrients in liquid medium (Bulut and Baysal, 2006). Metal precipitation is also common at high concentrations of $\mathrm{Pb}$ (II), thus modifying the actual $\mathrm{Pb}(\mathrm{II})$ ions available for interaction with the growing fungi (Sun and Shao, 2007). The ability of the fungi to grow on both forms of media at high $\mathrm{Pb}$ (II) concentrations compared to known literature heavily suggests not just tolerance but physiological processes that help manage their interaction with lead in liquid media (Acharya et al., 1999).

Increasing uptake is observed in all isolates from $500-3000 \mu \mathrm{g} / \mathrm{mL} \mathrm{Pb}$ (II) except for both $P$. canescens and Talaromyces $s p$. that have lower $\mathrm{q}$ at $3000 \mu \mathrm{g} / \mathrm{mL}$ than at $2000 \mu \mathrm{g} / \mathrm{mL} \mathrm{Pb}$ (II). This agrees with results for A. niger, P. simplicissimum and T. asperellum where a depression in uptake capacity for $\mathrm{Pb}$ (II) in liquid medium was reduced from $250 \mu \mathrm{g} / \mathrm{mL}$ to $300 \mu \mathrm{g} / \mathrm{mL} \mathrm{Pb}$ (II) (Iskandar et al., 2011). It has been shown that increasing initial HM concentrations result to higher $\mathrm{Pb}$ (II) removal in various fungal species grown on liquid medium (Akar and Tunali, 2006; Iram et al., 2015; Melgar et al., 2007). This has been explained heavily by mass transfer biosorption kinetics (Yalçin et al., 2010) where increasing concentrations provide a driving force to overcome transfer resistances (Fan et al., 2008) necessary for metals to bind to various groups in the cell wall (Say et al., 2003b). This is facilitated by increased metal collisions with the fungal wall being more pronounced in higher HM concentrations (Aksu and Tezer, 2005). However, in Penicillium sp Psf-2, it was shown that the ability to 
respond to increasing $\mathrm{Pb}$ (II) concentrations was influenced heavily by bioaccumulation in living tissue (Sun and Shao, 2007). This has also been shown in several genera of fungi such as A. macrosporus (Melgar et al., 2007) C. lacera, M. pelagica (Taboski et al., 2005), A. fumigatus, $P$. janthanellum and $P$. simplicissimum (Iskandar et al., 2011) and T. viride, (Šimonovičová, 2008) at varying concentrations of $\mathrm{Pb}(\mathrm{II})$.

Recorded uptake values for $\mathrm{Pb}(\mathrm{II})$ differ from one fungal species to another (Ahmad et al., 2011; Leitão, 2009). While all isolates have relatively comparable $q$ at each test concentration, $P$. canescens has the lowest $q$ for each concentration except at $3000 \mu \mathrm{g} / \mathrm{mL}$ where the $\mathrm{Pb}(\mathrm{II})$ uptake of $P$. simplicissimum drops $97.37 \%$ to $35.75 \%$. These changes in uptake capacity between species reacting to changes in HM concentration are expected, since the bisorption and bioaccumulation of deleterious HMs is both inter- and intra- species specific, varying even among closely grouped fungal species (Gadd, 2007; Vodnik et al., 1998) being heavily dependent on species potential and the ecology to which the fungus is exposed to (Udochukwu et al., 2014).

The recorded $\mathrm{Pb}$ (II) uptake in this study are higher than most recorded values in literature for the Penicillim isolates. For $P$. canescens, reports are at $213.2 \mathrm{mg} / \mathrm{g}$ (Say et al., 2003b), for $P$. simplicissimum published values range from 17.61 (Iskandar et al., 2011) to 76.90 at $250 \mu \mathrm{g} / \mathrm{mL}$ (Fan et al., 2008), both lower than the maximum reported values for the P. canescens $(407.4 \pm 5.7$ at $2000 \mu \mathrm{g} / \mathrm{mL})$ and $P$. simplcissimum $(412.6 \pm 4.9$ at $2000 \mu \mathrm{g} / \mathrm{mL})$ in this work. There are no reports of Talaromyces species with $\mathrm{Pb}$ (II) uptake capacities specifically performed either through biosorption or bioaccumulation. The remarkable uptake of the T. macrosporus $(601.0 \pm 3.6$ at $3000 \mu \mathrm{g} / \mathrm{mL})$ and Talaromyces $s p$. $(519.1 \pm$ 2.6 at $2000 \mu \mathrm{g} / \mathrm{mL}$ ) show that all four species have potential for use as material for the remediation of $\mathrm{Pb}(\mathrm{II})$ from the environment.

\section{Conclusions}

The remarkable tolerance and uptake of each of $P$. canescens, P. simplcissimum T. macrosporus and Talaromyces sp. are demonstrated in this study. All isolates can tolerate increased $\mathrm{Pb}$ (II) concentrations on both solid and liquid medium, comparable to results for other fungal species in literature. The initial concentration of $\mathrm{Pb}$ (II) does not appear to have significant influence on the removal rates of the Talaromyces isolates but increases removal in Penicillium isolates when grown in liquid medium. Uptake of $\mathrm{Pb}$ (II) increases with increasing $\mathrm{Pb}(\mathrm{II})$ concentration up to $2000 \mu \mathrm{g} / \mathrm{mL}$ for all isolates except $T$. macorsporus, where uptake is increased until $3000 \mu \mathrm{g} / \mathrm{mL}$. The uptake rates presented in this study are higher than those recorded in literature. The high removal rates and uptake abilities of all isolates on liquid media compared to current literature make them ideal candidates for $\mathrm{Pb}(\mathrm{II})$ biosorption and bioaccumulation studies.

\section{Author Contributions}

ZAN Maini is the project leader who was responsible for overseeing the entire work, drafting the manuscript and assisting in the PCR-based identification of the fungal strains as well as performing statistical analyses. KMJ Aribal was responsible for preparation of stock solutions reagents and mixtures, maintaining the fungal cultures, performing additional TI replications and experiments, and assisted in the performance of the statistical analysis. JAD Frejas \& LAM were responsible for performing environmental sampling, initial screening, purification of the cultures, as well as performing the PCR-based identification of the fungal strains. Narag RMA \& Melad JKUT performed the removal and uptake tests, as well as initial TI measurements. PCG Gulpeo IA Navarrete and Lopez CM assisted with the over-all design of the experiment, screening of $\mathrm{Pb}(\mathrm{II})$ tolerant species, morphological identification, and determination of culture conditions on solid and liquid media and provided supervisory capacity on all levels of the work including assistance in reviewing and drafting the manuscript.

\section{Acknowledgements}

This research was supported by the Ateneo de Manila University Research Council under grant URC-16-12.

\section{Conflict of Interest}

Authors have no conflict of interest in the research reported here.

\section{References}

Abd El Hameed, A.H., Eweda, W.E., Abou-Taleb, K. A.A. and Mira, H.I., 2015. Biosorption of uranium and heavy metals using some local fungi isolated from phosphatic fertilizers. Annals of Agricultural Sciences, 60(2), 345-351. https://doi.org/10.1016/j.aoas.2015.10.003

Acharya, C., Acharya, S., Kar, R.N. and Sukla, L.B., 1999. Toxic effect of lead on the growth of Penicillium species. Journal of the Indian Institute of Science, 79, 295 - 302.

Adeogun, A.I., Kareem, S.O., Durosanya, J.B. and Balogun, E.S., 2012. Kinetics and equilibrium parameters of biosorption and bioaccumulation of lead ions from aqueous solutions by. Journal of Microbiology, Biotechnology and Food Sciences, 1(5), 1221-1234.

Ahmad, I., Ahmad, F. and Pichtel, J., 2011. Metal tolerance and biosorption potential of soil fungi: applications for a green and clean water treatment technology. In: Ahmad, I., Ahmad, F., and Pitchel, J. (eds) Microbes and microbial technology: Agricultural and environmental applications (pp321 - 361), New York, USA: Springer-Verlag. https://doi.org/10.1007/978-1-4419-7931-5_ 13

Akar, T. and Tunali, S., 2006. Biosorption characteristics of Aspergillus flavus biomass for removal of $\mathrm{Pb}$ (II) and $\mathrm{Cu}$ (II) ions from an aqueous solution. Bioresource Technology, 97(15), 
$1780-1787$. https://doi.org/10.1016/j.biortech.2005.09.009

Aksu, Z. and Tezer, S., 2005. Biosorption of reactive dyes on the green alga Chlorella vulgaris. Process Biochemistry, 40(3-4), 1347-1361.

Ayangbenro, A.S. and Babalola, O.O., 2017. A new strategy for heavy metal polluted environments: A review of microbial biosorbents. International Journal of Environmental Research and Public Health, 14(1), 1 - 16. https://doi.org/10.3390/ijerph14010094

Aytar, P., Gedikli, S., Buruk, Y., Cabuk, A. and Burnak, N., 2014. Lead and nickel biosorption with a fungal biomass isolated from metal mine drainage: Box-Behnken experimental design. International Journal of Environmental Science and Technology, 11(6), 1631-1640. https://doi.org/10.1007/s13762-013-0354-5

Bellion, M., Courbot, M., Jacob, C., Blaudez, D. and Chalot, M., 2006. Extracellular and cellular mechanisms sustaining metal tolerance in ectomycorrhizal fungi. FEMS Microbiology Letters, 254(2), 173-181. https://doi.org/10.1111/j.1574-6968.2005.00044.x

Bengtsson, L., Johansson, B., Hackett, T.J., McHale, L. and McHale, A.P., 1995. Studies on the biosorption of uranium by Talaromyces emersonii CBS 814.70 biomass. Applied Microbiology and Biotechnology, 42(5), 807-811. https://doi.org/10.1007/BF00171965

Bulut, Y., and Baysal, Z., 2006. Removal of $\mathrm{Pb}$ (II) from wastewater using wheat bran. Journal of Environmental Management, 78(2), 107-113. https://doi.org/10.1016/j.jenvman.2005.03.010

Chen, S.H., Ng, S.L., Cheow, Y.L., and Ting, A.S.Y., 2017. A novel study based on adaptive metal tolerance behavior in fungi and SEM-EDX analysis. Journal of Hazardous Materials, 334, 132-141. https://doi.org/10.1016/j.jhazmat.2017.04.004

Chojnacka, K., 2010. Biosorption and bioaccumulation - the prospects for practical applications. Environment International, 36(3), 299-307. https://doi.org/10.1016/j.envint.2009.12.001

Dey, P., Gola, D., Mishra, A., Malik, A., Singh, D.K., Patel, N. and Jehmlich, N., 2016. Comparative performance evaluation of multi-metal resistant fungal strains for simultaneous removal of multiple hazardous metals. Journal of Hazardous Materials, 318, 679-685. https://doi.org/10.1016/j.jhazmat.2016.07.025

Dixit, R., Malaviya, D., Pandiyan, K., Singh, U.B., Sahu, A., Shukla, R. and Paul, D., 2015. Bioremediation of heavy metals from soil and aquatic environment: an overview of principles and criteria of fundamental processes sustainability, 7(2), 2189-2212. https://doi.org/10.3390/su7022189

Elia, A.C., Galarini, R., Dörr, A.J.M., and Taticchi, M. I., 2006. Bioaccumulation of heavy metals, organochlorine pesticides, and detoxication biochemical indexes in tissues of ictalurus melas of lake trasimeno. Bulletin of Environmental Contamination and Toxicology, 76(1), 132-139. https://doi.org/10.1007/s00128-005-0899-1

Ellis, M.B., and Ellis J.P., 1997. Microfungi on Land Plants: An Identification Handbook, (pp. 1 - 868), Croom Helm, London: Richmond Publishers.
Ezzouhri, L., Castro, E., Moya, M., Espinola, F., and Lairini, K., 2009. Heavy metal tolerance of filamentous fungi isolated from polluted sites in Tangier, Morocco. African Journal of Microbiology Research, 3(2), 35-48. https://doi.org/10.4236/nr.2012.34022

Fan, T., Liu, Y., Feng, B., Zeng, G., Yang, C., Zhou, M. and Wang, X., 2008. Biosorption of cadmium(II), zinc(II) and lead(II) by Penicillium simplicissimum: Isotherms, kinetics and thermodynamics. Journal of Hazardous Materials, 160(2-3), 655-661. https://doi.org/10.1016/j.jhazmat.2008.03.038

Gadd, G.M., 2007. Geomycology: biogeochemical transformations of rocks, minerals, metals and radionuclides by fungi, bioweathering and bioremediation. Mycological Research, 111(1), 3-49. https://doi.org/10.1016/j.mycres.2006.12.001

Gilman, J.C., 2001. A Manual of Soil Fungi, 2nd ed., (pp. 1 -400), New Delhi, India: Daya Publishing.

Gorbushina A.A. and Krumbein W.E., 2000. Subaerial microbial mats and their effects on soil and rock. In: Riding R.E., Awramik S.M. (eds) Microbial Sediments, (pp 161-170), Berlin, Germany: Springer. https://doi.org/10.1007/978-3-662-04036-2_ 18

Gube M., 2016. Fungal molecular response to heavy metal stress. In: Esser, K., Hoffmeister, D. (eds) Biochemistry and molecular biology. The mycota (A comprehensive treatise on fungi as experimental systems for basic and applied research) vol III (pp. 47-68), Cham, Switzerland: Springer. https://doi.org/10.1007/978-3-319-27790-5_ 4

Hafez, N., AbdelRazek, A.S., and Hafez, M.B., 1997. Accumulation of some heavy metals on Aspergillus flavus. Journal of Chemical Technology and Biotechnology, 68(1), 19-22. https://doi.org/10.1002/(sici)10974660(199701)68:1¡19::aid-jctb508;3.0.co;2-k

He, J., and Chen, J.P., 2014. A comprehensive review on biosorption of heavy metals by algal biomass: Materials, performances, chemistry, and modeling simulation tools. Bioresource Technology, 160, 67-78. https://doi.org/10.1016/j.biortech.2014.01.068

He, Z.L., Yang, X.E. and Stoffella, P.J., 2005. Trace elements in agroecosystems and impacts on the environment. Journal of Trace Elements in Medicine and Biology, 19(2-3), 125-140. https://doi.org/10.1016/j.jtemb.2005.02.010

Iram, S., Ahmad, I., Javed, B., Yaqoob, S., Akhtar, K., Kazmi, M. R., and Badar-uz-Zaman., 2009. Fungal tolerance to heavy metals. Pakistan Journal of Botany, 41(5), 2583-2594.

Iram, S., Shabbir, R., Zafar, H. and Javaid, M., 2015. Biosorption and bioaccumulation of copper and lead by heavy metalresistant fungal isolates. Arabian Journal for Science and Engineering, 40(7), 1867-1873. https://doi.org/10.1007/s13369-015-1702-1

Iskandar, N.L., Zainudin, N.A.I.M. and Tan, S.G., 2011. Tolerance and biosorption of copper $(\mathrm{Cu})$ and lead $(\mathrm{Pb})$ by filamentous fungi isolated from a freshwater ecosystem. Journal of Environmental Sciences, 23(5), 824-830. https://doi.org/10.1016/S1001-0742(10)60475-5

Jacob, J.M., Bardhan, S., and Balakrishnan R.B., 2013. Selenium and Lead tolerance in fungi isolated from sea water. International Journal of Innovative Research in Science, Engineering and Technology, 2(7), 2975-2982. 
Jentschke, G. and Godbold, D. L., 2000. Metal toxicity and ectomycorrhizas. Physiologia Plantarum, 109(2), 107-116. https://doi.org/10.1034/j.1399-3054.2000.100201.x

Joshi, P.K., Swarup, A., Maheshwari, S., Kumar, R. and Singh, N., 2011. Bioremediation of heavy metals in liquid media through fungi isolated from contaminated sources. Indian Journal of Microbiology, 51(4), 482-487. https://doi.org/10.1007/s12088-011-0110-9

Kalac, P. and Svoboda, L., 2000. A review of trace element concentrations in edible mushrooms. Food Chemistry, 69, 273-281. https://doi.org/10.1016/S0308-8146(99)00264-2

Kapahi, M. and Sachdeva, S., 2017. Mycoremediation potential of Pleurotus species for heavy metals: a review. Bioresources and Bioprocessing, 4(1), 1-9 https://doi.org/10.1186/s40643-017-0162-8

Kiene, R.P. and Slezak, D., 2006. Low dissolved DMSP concentrations in seawater revealed by small-volume gravity filtration and dialysis sampling. Limnology and Oceanography: Methods, 4(4), 80-95. https://doi.org/10.4319/lom.2006.4.80

Kim, H.C., Jang, T.W., Chae, H.J., Choi, W.J., Ha, M.N., Ye, B.J. and Hong, Y.S., 2015. Evaluation and management of lead exposure. Annals of occupational and environmental medicine, 27(1), 30. https://doi.org/10.1186/s40557-015-0085-9

Leitão, A. L., 2009. Potential of Penicillium species in the bioremediation field. International Journal of Environmental Research and Public Health, 6(4), 1393-1417. https://doi.org/10.3390/ijerph6041393

Machido, D., Ezeonuegbu, B., and Yakubu, S.E., 2011. Capacity of isolates of six genera of filamentous fungi to remove lead, nickel and cadmium from refinery effluent. Journal of Environment and Earth Science, 6(8), 72-76. Retrieved from http://iiste.org/Journals/index.php/JEES/article/view/32545

Massaccesi, G., Romero, M.C., Cazau, M.C. and Bucsinszky, A.M., 2002. Cadmium removal capacities of filamentous soil fungi isolated from industrially polluted sediments, in La Plata (Argentina). World Journal of Microbiology and Biotechnology, 18(9), 817-820. https://doi.org/10.1023/A:1021282718440

Melgar, M.J., Alonso, J. and García, M.A., 2007. Removal of toxic metals from aqueous solutions by fungal biomass of Agaricus macrosporus. Science of the Total Environment, 385(1-3), 12-19. https://doi.org/10.1016/j.scitotenv.2007.07.011

Mohsenzadeh, F. and Shahrokhi, F., 2014. Biological removing of cadmium from contaminated media by fungal biomass of Trichoderma species. Journal of Environmental Health Science and Engineering, 12(1), 1-7. https://doi.org/10.1186/2052-336X-12-102

Nagamani, A., Kunwar, I.K. and Manoharachary, C., 2006. Handbook of soil fungi, (pp 1-477), New Delhi, India: K. International Pvt. Ltd.

Navarrete, I.A., Gabiana, C.C., Dumo, J.R.E., Salmo, S.G., Guzman, M.A.L.G., Valera, N.S., and Espiritu, E.Q., 2017. Heavy metal concentrations in soils and vegetation in urban areas of Quezon City, Philippines. Environmental monitoring and assessment, 189(4), 145. https://doi.org/10.1007/s10661-017-5849-y

Oladipo, O.G., Awotoye, O.O., Olayinka, A., Bezuidenhout, C.C., and Maboeta, M.S., 2018. Heavy metal tolerance traits of filamentous fungi isolated from gold and gemstone mining sites. Brazilian Journal of Microbiology, 49(1), 29-37. https://doi.org/10.1016/j.bjm.2017.06.003

Ona, L.F., Alberto, A.M.P., Prudente, J.A., and Sigua, G.C., 2006. Levels of lead in urban soils from selected cities in a central region of the Philippines. Environmental Science and Pollution Research, 13(3), 177-183. https://doi.org/10.1065/espr2005.08.275

Oso, B.A., Olagunji, M.O. and Okiki, P.A., 2015. Lead tolerance and bioadsorption potentials of indigenous soil fungi in Ado Ekiti, Nigeria. European Journal of Experimental Biology, 5(9), 15-19.

Ostrea, E.M., Ostrea, A.M., Villanueva-Uy, M.E., Chiodo, L. and Janisse, J., 2015. Alluvial and riparian soils as major sources of lead exposure in young children in the Philippines: the role of floods. Environmental Science and Pollution Research, 22(7), 5082-5091. https://doi.org/10.1007/s11356-014-3908-2

Rhodes, C.J., 2014. Mycoremediation (bioremediation with fungi)growing mushrooms to clean the earth. Chemical Speciation and Bioavailability, 26(3), 196-198. https://doi.org/10.3184/095422914X14047407349335

Riddell, T., 2007. Elevated blood-lead levels among children living in the rural Philippines. Bulletin of the World Health Organization, 85(9), 674-680. https://doi.org/10.2471/blt.06.036137

Romero, M.C., Reinoso, E.H., Urrutia, M.I., and Kiernan, A.M., 2006. Biosorption of heavy metals by Talaromyces helicus: A trained fungus for copper and biphenyl detoxification. Electronic Journal of Biotechnology, 9(3), 221-226. https://doi.org/10.1016/j.toxlet.2006.04.004

Say, R., Yilmaz, N., and Denizli, A., 2003a. Biosorption of cadmium, lead, mercury, and arsenic ions by the fungus Penicillium purpurogenum. Separation Science and Technology, 38(9), 2039-2053. https://doi.org/10.1081/SS-120020133

Say, R., Yilmaz, N. and Denizli, A., 2003b. Removal of heavy metal ions using the fungus Penicillium canescens. Adsorption Science and Technology, 21(7), 643-650. https://doi.org/10.1260/026361703772776420

Šimonovičová, A., 2008. Use of mitosporic fungi for heavy metal removal from experimental water solutions. Czasopismo Techniczne, 105(2): 207-212.

Singh, R., Gautam, N., Mishra, A. and Gupta, R., 2011. Heavy metals and living systems: An overview. Indian Journal of Pharmacology, 43(3), 246. https://doi.org/10.4103/0253-7613.81505

Solon, O., Riddell, T., Quimbo, S., Butrick, E., Alyward, G., Bacate, M. and Peabody, J., 2008. Nutrition among children in the central Philippines. Journal of Pediatrics, 152(2), 237-244. https://doi.org/10.1016/j.jpeds.2007.09.008

Sun, F., and Shao, Z., 2007. Biosorption and bioaccumulation of lead by Penicillium sp. Psf-2 isolated from the deep sea sediment of the Pacific Ocean. Extremophiles, 11(6), 853-858. https://doi.org/10.1007/s00792-007-0097-7

Svecova, L., Spanelova, M., Kubal, M. and Guibal, E., 2006. Cadmium, lead and mercury biosorption on waste fungal biomass issued from fermentation industry. I. Equilibrium studies. Separation and Purification Technology, 52(1), 142-153. https://doi.org/10.1016/j.seppur.2006.03.024 
Taboski, M.A.S., Rand, T.G. and Piórko, A., 2005. Lead and cadmium uptake in the marine fungi Corollospora lacera and Monodictys pelagica. FEMS Microbiology Ecology, 53(3), 445-453. https://doi.org/10.1016/j.femsec.2005.02.009

Tong, S., Schirnding, Y.E.V. and Prapamontol, T., 2000. Environmental lead exposure: a public health problem of global dimensions. Bulletin of the World Health Organization, 78, 1068-1077.

Udochukwu, U., Nekpen, B.O., Udinyiwe, O.C. and Omeje, F. I., 2014. Bioaccumulation of heavy metals and pollutants by edible mushroom collected from Iselu market Benin-city. International Journal of Current Microbiology and Applied Sciences, 3(10), 52-57.

Valix, M. and Loon, L. O., 2003. Adaptive tolerance behaviour of fungi in heavy metals. Minerals Engineering, 16(3), 193-198. https://doi.org/10.1016/S0892-6875(03)00004-9

Valix, M., Tang, J. Y. and Malik, R., 2001. Heavy metal tolerance of fungi. Minerals Engineering, 14(5), 499-505. https://doi.org/10.1016/s0892-6875(01)00037-1

Vodnik, D., Byrne, A.R., and Gogala, N., 1998. The uptake and transport of lead in some ectomycorrhizal fungi in culture. Mycological Research, 102(8), 953-958. https://doi.org/10.1017/S0953756297005959

Wang, N., Xu, X., Li, H., Wang, Q., Yuan, L., and Yu, H., 2017. High performance and prospective application of xanthate-modified thiourea chitosan sponge-combined Pseudomonas putida and Talaromyces amestolkiae biomass for $\mathrm{Pb}$ (II) removal from wastewater. Bioresource Technology, 233, 58-66. https://doi.org/10.1016/j.biortech.2017.02.069

Wong, D.L., Merrifield-macrae, M.E., and Stillman, M.J., 2017. Lead (II) binding in metallothioneins, 17(Ii), 241-269. https://doi.org/10.1515/9783110434330-009

Yalçin, E., Çavuşoĝlu, K. and Kinalioĝlu, K., 2010. Biosorption of $\mathrm{Cu}^{2+}$ and $\mathrm{Zn}^{2+}$ by raw and autoclaved Rocella phycopsis. Journal of Environmental Sciences, 22(3), 367-373. https://doi.org/10.1016/S1001-0742(09)60117-0

Yetis, U., Dolek, A., Dilek, F. B. and Ozcengiz, G., 2000. The removal of $\mathrm{Pb}$ (II) by Phanerochaete chrysosporium. Water Research, 34(16), 4090-4100. https://doi.org/10.1016/S0043-1354(00)00155-X

Zafar, S., Aqil, F. and Ahmad, I., 2007. Metal tolerance and biosorption potential of filamentous fungi isolated from metal contaminated agricultural soil. Bioresource Technology, 98(13), 2557-2561.

https://doi.org/10.1016/j.biortech.2006.09.051

Zhang, S., Zhang, X., Chang, C., Yuan, Z., Wang, T., Zhao, Y. and $\mathrm{Li}, \mathrm{X}$., 2016. Improvement of tolerance to lead by filamentous fungus Pleurotus ostreatus HAU-2 and its oxidative responses. Chemosphere, 150, 33-39.

https://doi.org/10.1016/j.chemosphere.2016.02.003

Zucconi, L., Ripa, C., Alianiello, F., Benedetti, A., and Onofri, S., 2003. Lead resistance sorption accumulation in a Paecilomyces lilacinus strain. Biology and Fertility of Soils, 37(1), 17-22.

https://doi.org/10.1007/s00374-002-0555-4 